\title{
Senile Cataract in Patients with Diabetes with and Without Diabetic Retinopathy: A Community-Based Comparative Study
}

\author{
Khalid Mohammad Alabdulwahhab ${ }^{1} \mathbb{D}$
}

Received: 5 August 2021 / Accepted: 14 November 2021 / Published online: 7 December 2021

(C) The Author(s) 2021

\begin{abstract}
Aim We compare the incidence rates of cataract in persons with diabetes with and without diabetic retinopathy in Saudi Arabia, for the first time. In addition, we explored the role of new factor, diabetes age of onset and several other known factors. Methods In a community-based cross-sectional study, 334 persons with diabetes type 2 were randomly selected from a diabetic register. Detailed history and comprehensive ophthalmic examination was done at an eye clinic. Body Mass Index, blood pressure and glycosylated hemoglobin were also recorded.

Results In 668 eyes, cataract and diabetic retinopathy were present in $35.5 \%$ and 32.2\%, respectively. Diabetic retinopathy, age, duration of diabetes and systolic BP were found to be independent risk factors for cataract. Whereas, gender, BMI, $\mathrm{HbA} 1 \mathrm{c}$ use of insulin and diastolic BP have no significant association with cataract. Persons with cataract had significantly higher age of onset of diabetes. Most of the cataracts were cortical followed by PSC, while minority were nuclear.

Conclusion DR is an independent risk factor of developing cataract in persons with diabetes. Others are age, duration of DM and hypertension. Age-of-onset of DM is a new factor we report it to be significantly associated with cataract.
\end{abstract}

Keywords Type 2 diabetes $\cdot$ HbA1c $\cdot$ Insulin $\cdot$ Saudi Arabia $\cdot$ Hypertension $\cdot$ Risk factor $\cdot$ Age-of-onset

\section{Introduction}

Diabetes mellitus (DM) is one of the most common chronic systemic diseases and a major cause of visual loss worldwide [1-3]. According to the International Diabetes Federation, approximately 463 million adults aged 20-79 years were living with diabetes and by 2045 this is expected to rise to 700 million [4]. Among the top 10 countries in the world for diabetes prevalence in 2010, Saudi Arabia occupies the third place and is expected to continue to retain this position until 2030 [5]. The prevalence of DM in Saudi Arabia, according to the latest local study, was 30\% [6].

DM can affect all ocular tissues; one of them is the human lens, which causes lens opacification (cataract). Globally, cataracts remain the 2nd-leading cause of blindness, affecting approximately 18 million people [7]. Cataract is a major cause of visual impairment in the general population $[8,9]$ as well as in the population with diabetes [10-12]. Further,

Khalid Mohammad Alabdulwahhab

k.alabdulwahhab@mu.edu.sa

1 College of Medicine, Majmaah University, 4315, King Abdulaziz, Majmaah 6514-15362, Kingdom of Saudi Arabia a causal biochemical relationship between DM and cataract development has been proven in scientific research [13-15]. Clinical studies have revealed that DM is one of the wellknown risk factors for cataract, and that cataracts occur 2-5 times more frequently in patients with DM than in those without DM [13, 16-19].

DM and cataracts, as independent diseases, are major health concerns and impose immense economic burden, especially in developing countries where DM and cataract treatment options are not optimal [20]. Furthermore, aging is a known risk factor for both diseases, which causes further burden on health care services [21]. To effectively prevent and treat blindness, it is important to identify the risk factors that play a role in the association between DM and cataract.

Despite extensive research on DM and cataract comorbidities, data from developing low- and middle-income countries are scarce [22]. Therefore, in this population-based study, we aimed to assess the incidence rates of cataract in patients with diabetic retinopathy (DR) and compare the data with individuals without DR from a population with diabetes in a developing country, Saudi Arabia. Furthermore, we explored the role of several other clinical factors and their association with cataract and cataract subtypes in patients 
with diabetes, such as age of onset, duration and control, blood pressure, and obesity.

Isolating such manageable factors, leading to the development of cataracts, will help health authorities build health programs that will lower the need for cataract surgery. Furthermore, it is especially important to reduce the demand for health resources in low-income countries.

\section{Subjects}

\subsection{Study Design and Patients}

This community-based, cross-sectional study aimed to determine the prevalence of senile cataract in patients with type $2 \mathrm{DM}$ with DR compared to those without DR. The study subjects were residents of Majmaah, a medium-sized city in central Saudi Arabia with a population of approximately 60,000. The DM register is located at the eight primary health care centers (PHC) distributed throughout the city, which is continuously updated as new patients are diagnosed.

All patients with type $2 \mathrm{DM}$ included in the diabetes registry ( $\mathrm{n}=1890$ patients) were included in the study population. The sample was chosen from all PHCs with an equivalent proportion of the number of patients with type $2 \mathrm{DM}$ in each PHC using a systematic random sampling technique. The chosen patients were given appointments at the eye clinic at the central hospital of the city for examination.

\subsection{Ethical Statement}

The study was conducted from February 2020 to March 2021. This study was approved by the Ethical Review Committee of Majmaah University. Written informed consent from the patients was obtained before conducting the interviews and examinations.

\subsection{Materials and Methods}

A detailed history, including data on demographics, past history of diabetes, and ocular problems was obtained from all patients. Height and weight were measured to calculate the body mass index (BMI). Blood pressure (BP) was measured using a blood pressure monitor (GE Dinamap). The patient was considered hypertensive if they reported hypertension in their medical history, or if their BP readings satisfied the World Health Organization definition of hypertension, (systolic of $\geq 140$ or diastolic of $\geq 90$ ) [23]. All patients underwent blood tests for glycosylated hemoglobin (HbAlc).

Best corrected visual acuity was measured using a Snellen distance vision screen by an optometrist, and then a senior ophthalmologist performed a comprehensive ophthalmic examination. The crystalline lens was assessed using a slitlamp bio-microscope (Haag Streit, Germany). The cataract grade was determined according to the Lens Opacity Classification System (LOCS) III with direct reference to photographic standards at the slit lamp [24]. Patients with pseudophakic eyes were considered to have cataracts in the analysis. Pupils were dilated using $0.5 \%$ tropicamide and the posterior segment was evaluated using an indirect ophthalmoscope (Keeler, UK), as well as using a slit-lamp biomicroscope and +90-diopter lens (Volk, USA). The status of DR in each eye was determined using the International Clinical Diabetic Retinopathy and Diabetic Macular Edema Disease Severity scales [25].

\subsection{Statistical Analysis}

We used a power analysis and sample size software (PASS) to calculate the sample size. A sample size of 334 achieves $90 \%$ power to detect a clinically meaningful difference of 0.08 , with a known standard deviation of 0.506 and significance level of 0.05 . The calculation was further confirmed by placing the aforementioned values in the following formula, which yielded the same number of patients (334).

$n=((\sigma d) 2(Z \beta+Z \alpha / 2) 2) /$ difference2

where $n$ is the sample size, $\sigma$ is the standard deviation of the within-pair difference, difference is the clinically meaningful difference, $Z \beta$ corresponds to power $(1.28=90 \%$ power $)$. $Z \alpha / 2$ corresponds to two-tailed significance level (1.96 for $\alpha=0.05$ ).

The data were analyzed using SPSS (version 26.0; IBM Corp., Armonk, NY, USA) and Microsoft Power BI 2021. Normality of the data was checked using the one-sample Kolmogorov-Smirnov test. Median (25th-75th quartiles) were reported for non-normally distributed quantitative variables. Categorical variables were reported as frequencies and percentages. A one-sample chi-square test was used to examine the difference in the observed frequencies of cataract location. The Mann-Whitney $U$ test was used to compare various anthropometric and clinical variables in the presence and absence of cataracts. Pearson chi-square test was applied to identify the associations between anthropometric and clinical parameters among patients with diabetes with and without cataract. Post hoc tests were applied in cases of significant chi-square values using the Bonferroni adjustment. Binary logistic regression with backward conditional approach was applied to observe the log-odds between cataract (yes, no) and study variables. The ranking of the significant independent variables was performed using Wald statistics. Differences were considered statistically significant at $\alpha$ value of $0.05(p<0.05)$. 


\section{Results}

A total of 668 eyes of 334 patients with type 2 DM were examined. Cataract was present in $35.5 \%(n=237)$ of the eyes; among them, 76 eyes (32\%) were pseudophakic. The majority of the patients $(595,89.1 \%)$ were older than 40 years. Almost two-thirds of the patients were male and hypertensive, $424(62.7 \%)$ and $419(62.7 \%)$, respectively. Nearly half of the patients $(328,49.1 \%)$ were obese and approximately one-fourth of them $(172,25.6 \%)$ were on insulin. DR was present in almost one-third of the examined eyes $(215,32.2 \%)$ and most of the cases $(194,90.2 \%)$ were non-proliferative diabetic retinopathy (non-PDR). CSME was found in 89 eyes (13.3\%). The detailed results are presented in Table 1. Anthropometric and clinical data variables were not normally distributed; the median (25th-75th quartile) value for the whole study sample is presented in Fig. 1.

From our sample, those with cataract $(n=237)$ were significantly older $(p<0.001)$, had lower weight $(p=0.022)$, had a longer duration of diabetes $(p<0.001)$, had a higher age of onset of diabetes $(p<0.001)$, and had higher systolic BP $(p<0.001)$ than those without cataract $(n=431)$. However, no significant difference was observed in the height $(p=0.352)$, BMI $(p=0.067)$, diastolic BP $(p=0.883)$ or HbA1c level $(p=0.112)$ between the two groups (Table 2$)$.

DR and cataract were significantly associated $(p<0.001)$, and post hoc tests showed that DR was significantly present in patients with cataracts $(106,49.4 \% ; p<0.001)$. Moreover, a significant association was observed between age and cataract $(p<0.001)$, and the Bonferroni-adjusted post hoc test showed that cataract developed significantly more in patients with diabetes aged $>40$ years $(225,37.8 \% ; p<0.001)$. Patient sex and cataract were also significantly associated $(p=0.012)$. Post hoc tests revealed that cataract incidence was significantly higher in males $(164,38.7 \%)$ than in females $(71,29.1 \% ; p=0.027)$. Hypertension and cataract were significantly associated $(p=0.001)$, and the post hoc test showed that the majority of the patients with cataracts were hypertensives $(166,39.6 \% ; p<0.001)$. However, no significant association was observed between cataract and BMI category $(p=0.302)$, type of medication $(p=0.509)$, stages of DR $(p=0.102)$, stages of non-PDR $(p=0.194)$, or CSME ( $p=0.915$; Table 3 ). Results of the one-sample chi-square test showed that most of the cataracts were cortical $(73,45.3 \%)$, followed by posterior sub-capsular cataract (PSC) $(49,30.5 \%)$, mixed $(25,15.5 \%)$ and nuclear sclerosis (NS) $(14,8.7 \% ; p<0.001)$.

Two binary logistic regression models were used separately. In model 1 (unadjusted), the dependent variable was cataract (yes, no) and the independent variables were DR, age, sex, and hypertension, which were chosen based on their significance from Table 3. Results showed
Table 1 Socio-demographic, anthropometric and clinical characteristics of patients $(n=668)$

\begin{tabular}{|c|c|c|}
\hline Factor & $N$ & $\%$ \\
\hline \multicolumn{3}{|l|}{ Age } \\
\hline$\leq 40$ years & 73 & 10.9 \\
\hline$>40$ years & 595 & 89.1 \\
\hline \multicolumn{3}{|l|}{ Gender } \\
\hline Female & 244 & 36.6 \\
\hline Male & 424 & 63.4 \\
\hline \multicolumn{3}{|l|}{ Hypertension } \\
\hline No & 249 & 37.3 \\
\hline Yes & 419 & 62.7 \\
\hline \multicolumn{3}{|l|}{ Medication } \\
\hline Insulin & 172 & 25.8 \\
\hline OHG & 470 & 70.4 \\
\hline Not taking medication & 26 & 3.8 \\
\hline \multicolumn{3}{|l|}{ Body mass index } \\
\hline Normal & 92 & 13.8 \\
\hline Overweight & 248 & 37.1 \\
\hline Obese & 328 & 49.1 \\
\hline \multicolumn{3}{|l|}{ Cataract $^{\mathrm{a}}$} \\
\hline No & 431 & 64.5 \\
\hline Yes & 237 & 35.5 \\
\hline \multicolumn{3}{|l|}{ Sub-type of cataract } \\
\hline Cortical & 73 & 45.3 \\
\hline Posterior sub-capsular cataracts & 49 & 30.5 \\
\hline Nuclear sclerosis & 14 & 8.7 \\
\hline Mixed & 25 & 15.5 \\
\hline \multicolumn{3}{|l|}{ Diabetic retinopathy (DR) } \\
\hline No & 453 & 67.8 \\
\hline Yes & 215 & 32.2 \\
\hline \multicolumn{3}{|l|}{ Stage of diabetic retinopathy (DR) } \\
\hline Non-proliferative diabetic retinopathy & 194 & 90.2 \\
\hline Proliferative diabetic retinopathy (PDR) & 21 & 9.8 \\
\hline \multicolumn{3}{|c|}{ Stage of non-proliferative diabetic retinopathy } \\
\hline Mild & 104 & 53.6 \\
\hline Moderate & 73 & 37.6 \\
\hline Severe & 17 & 8.8 \\
\hline \multicolumn{3}{|l|}{ Clinically significant macular edema } \\
\hline No & 579 & 86.7 \\
\hline Yes & 89 & 13.3 \\
\hline
\end{tabular}

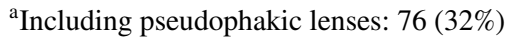

that patients with DR were 2.464 times more likely to develop cataracts [odds ratio $=2.464 ; 95 \%$ confidence interval $(\mathrm{CI})=-1.752$ to $3.465, p<0.001]$, and diabetics aged $>40$ years were 4.398 times more likely to develop cataracts than those aged $\leq 40$ years (odds ratio $=4.398$; $95 \% \mathrm{CI}=2.061-9.382, p<0.001]$. In males, the chance of developing cataract significantly increased by 1.525 times [odds ratio $=1.525 ; 95 \% \mathrm{CI}=1.089-2.137, p=0.014$ ). Similarly, in hypertensive subjects, the chance of developing cataract significantly increased 1.710 times [odds ratio $=1.710 ; 95 \% \mathrm{CI}=1.212-2.412, p=0.002$; Table 4 ). 


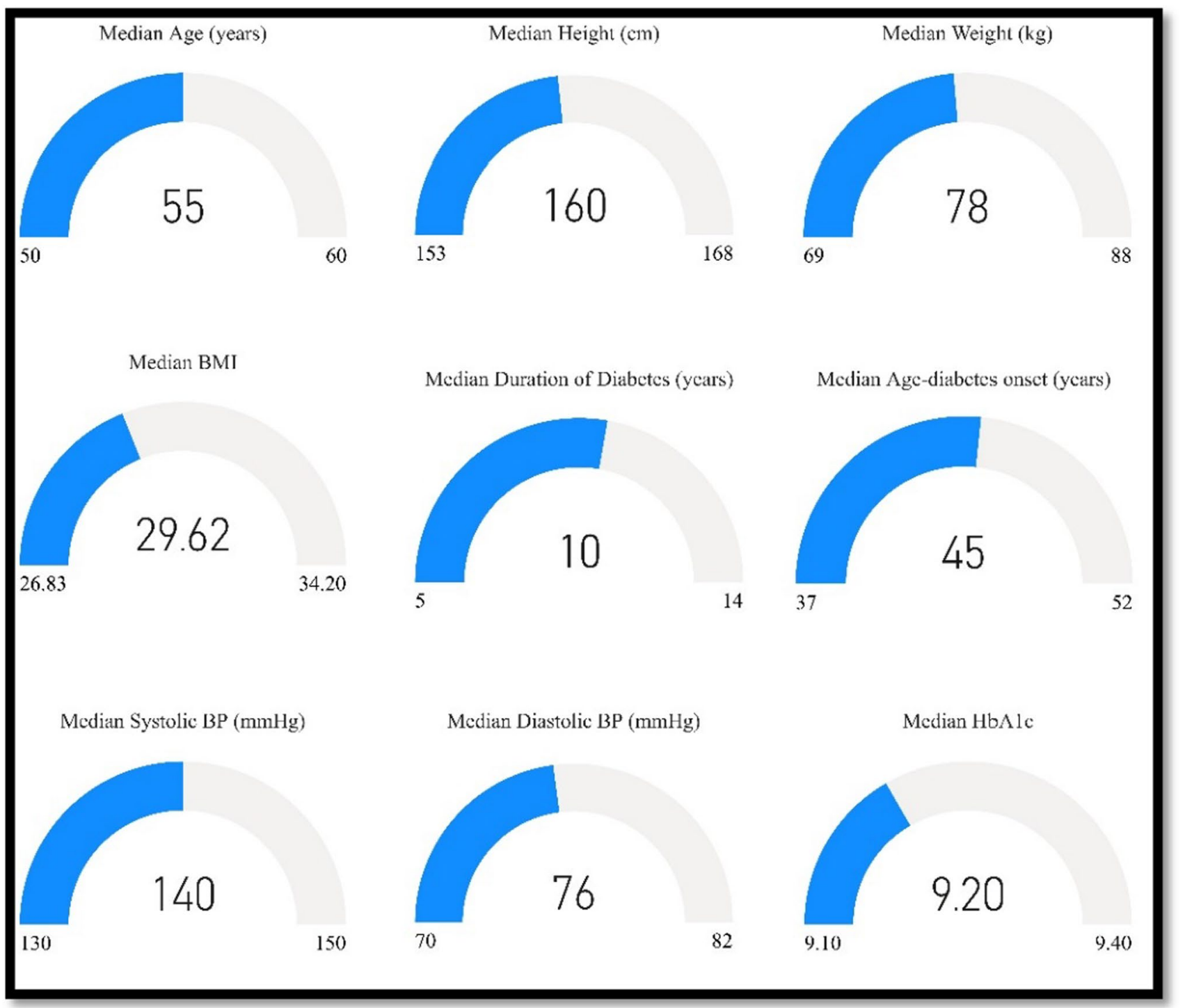

Fig. 1 Median (25th-75th quartiles) for various study parameters

Table 2 Comparison of anthropometric and clinical parameters among patients with and without cataract

\begin{tabular}{lllc}
\hline Parameters & Cataract & Cataract & $p$ value \\
& No & Yes \\
& $\begin{array}{l}\text { Median } \\
(25 \text { th-75th) quartile } \\
n=431\end{array}$ & $\begin{array}{l}\text { Median } \\
(25 \text { th-75th) quartile } \\
n=237\end{array}$ & \\
& $52.50(46-59)$ & $60(55-66)$ & $<\mathbf{0 . 0 0 1}^{*}$ \\
\hline Age & $160(153-168)$ & $162(154-168)$ & 0.352 \\
Height & $80(70-89)$ & $76(67-87.25)$ & $\mathbf{0 . 0 2 2}$ \\
Weight & $30.09(26.98-34.92)$ & $29.05(26.02-32.88)$ & 0.067 \\
BMI & $8(4-15)$ & $14(6-20)$ & $<\mathbf{0 . 0 0 1}^{*}$ \\
Duration of diabetes & $43(35-49)$ & $48(40-55.25)$ & $<\mathbf{0 . 0 0 1}^{*}$ \\
Age onset of diabetes & $138(130-150)$ & $140(130-160)$ & $<\mathbf{0 . 0 0 1 *}$ \\
Systolic blood pressure & $75(70-80.75)$ & $77(70-83)$ & 0.883 \\
Diastolic blood pressure & $9.20(9.20-9.40)$ & $5.60(5.20-6.37)$ & 0.112 \\
HbA1c & & & \\
\hline
\end{tabular}

*Statistically significant at $5 \%$ level of significance $B M I$ body mass index, $H b A l c$ hemoglobin A1c 
Table 3 Association of cataract with gender, BMI, and clinical parameters

\begin{tabular}{|c|c|c|c|c|}
\hline \multirow[t]{2}{*}{ Factor } & \multicolumn{3}{|l|}{ Cataract } & \multirow[t]{2}{*}{$p$ value } \\
\hline & $\begin{array}{l}\text { No } \\
n(\%)\end{array}$ & $\begin{array}{l}\text { Yes } \\
n(\%)\end{array}$ & Total & \\
\hline \multicolumn{5}{|l|}{ Age } \\
\hline $\begin{array}{l}<40 \text { years } \\
>40 \text { years }\end{array}$ & $\begin{array}{l}63(86.3) \\
370(62.2)\end{array}$ & $\begin{array}{l}10(13.7) \\
225(37.8)\end{array}$ & $\begin{array}{l}73 \\
595\end{array}$ & $<0.001 *$ \\
\hline \multicolumn{5}{|l|}{ Gender } \\
\hline $\begin{array}{l}\text { Female } \\
\text { Male }\end{array}$ & $\begin{array}{l}173(70.9) \\
260(61.3)\end{array}$ & $\begin{array}{l}71(29.1) \\
164(38.7)\end{array}$ & $\begin{array}{l}244 \\
424\end{array}$ & $0.012 *$ \\
\hline \multicolumn{5}{|l|}{$\begin{array}{l}\text { Body mass index cat- } \\
\text { egory }\end{array}$} \\
\hline $\begin{array}{l}\text { Normal } \\
\text { Obese } \\
\text { Overweight }\end{array}$ & $\begin{array}{l}56(61.4) \\
222(67.7) \\
155(62.5)\end{array}$ & $\begin{array}{l}36(38.6) \\
106(32.3) \\
93(37.5)\end{array}$ & $\begin{array}{l}92 \\
328 \\
248\end{array}$ & 0.302 \\
\hline \multicolumn{5}{|l|}{ Medication } \\
\hline $\begin{array}{l}\text { Insulin } \\
\text { Oral hypoglycemic } \\
(\mathrm{OHG}) \\
\text { Not taking medicatio }\end{array}$ & $\begin{array}{l}112(65.1) \\
305(64.8) \\
14(53.8)\end{array}$ & $\begin{array}{l}60(34.9) \\
165(35.2) \\
12(46.2)\end{array}$ & $\begin{array}{l}172 \\
470 \\
26\end{array}$ & 0.509 \\
\hline \multicolumn{5}{|l|}{ Hypertension } \\
\hline $\begin{array}{l}\text { No } \\
\text { Yes }\end{array}$ & $\begin{array}{l}180(72.3) \\
253(60.4)\end{array}$ & $\begin{array}{l}69(27.7) \\
166(39.6)\end{array}$ & $\begin{array}{l}249 \\
419\end{array}$ & $0.001 *$ \\
\hline \multicolumn{5}{|l|}{$\begin{array}{l}\text { Diabetic retinopathy } \\
\text { (DR) }\end{array}$} \\
\hline $\begin{array}{l}\text { No } \\
\text { Yes }\end{array}$ & $\begin{array}{l}324(71.5) \\
109(50.6)\end{array}$ & $\begin{array}{l}129(28.5) \\
106(49.4)\end{array}$ & $\begin{array}{l}453 \\
215\end{array}$ & $<0.001 *$ \\
\hline \multicolumn{5}{|l|}{$\begin{array}{l}\text { Stages of diabetic retin- } \\
\text { opathy }\end{array}$} \\
\hline $\begin{array}{l}\text { Non-PDR } \\
\text { PDR }\end{array}$ & $\begin{array}{l}101(52.1) \\
7(33.3)\end{array}$ & $\begin{array}{l}93(47.9) \\
14(66.7)\end{array}$ & $\begin{array}{l}194 \\
21\end{array}$ & 0.102 \\
\hline \multicolumn{5}{|l|}{ Stage of non-PDR } \\
\hline $\begin{array}{l}\text { Mild } \\
\text { Moderate } \\
\text { Severe }\end{array}$ & $\begin{array}{l}49(47.1) \\
38(52.1) \\
12(70.6)\end{array}$ & $\begin{array}{l}55(52.9) \\
35(47.9) \\
5(29.4)\end{array}$ & $\begin{array}{l}104 \\
73 \\
17\end{array}$ & 0.194 \\
\hline \multicolumn{5}{|l|}{ CSME } \\
\hline $\begin{array}{l}\text { No } \\
\text { Yes }\end{array}$ & $\begin{array}{l}374(64.6) \\
58(65.1)\end{array}$ & $\begin{array}{l}205(35.4) \\
31(34.9)\end{array}$ & $\begin{array}{l}579 \\
89\end{array}$ & 0.915 \\
\hline
\end{tabular}

*Statistically significant at $5 \%$ level of significance;

Non-PDR non-proliferative diabetic retinopathy, $P D R$ proliferative diabetic retinopathy, CSME clinically significant macular edema
In logistic regression model 2, the dependent variable was the presence and absence of cataract, whereas the independent variables were adjusted for age, sex, BMI, systolic BP, diastolic BP, duration of diabetes, HbA1c, and DR). The model chi-square value was significant at the $1 \%$ level of significance, confirming the appropriateness of the fitted model. The classification accuracy achieved using the fitted model was $76.9 \%$. The results showed that diabetics aged $>40$ years were 3.089 times more likely to develop cataracts than those aged $\leq 40$ years (adjusted odds ratio $=3.089 ; 95 \% \mathrm{CI}=1.401-6.814, p=0.005)$. Similarly, patients with DR were 1.668 times more likely to develop cataracts $(\mathrm{OR}=1.668 ; 95 \% \mathrm{CI}=1.135-2.451, p=0.009)$. As the duration of diabetes increased by 1 year, the chance of developing cataract significantly increased by 1.049 times (adjusted odds ratio $=1.049 ; 95 \% \mathrm{CI}=1.024-1.074$, $p<0.001)$. Moreover, with an increase of $1 \mathrm{mmHg}$ in systolic BP, the chance of developing cataract significantly increased by 1.010 times (adjusted odds ratio $=1.010 ; 95 \%$ $\mathrm{CI}=1.002-1.215, p=0.039)$. However, $\operatorname{sex}(p=0.390), \mathrm{BMI}$ $(p=0.460), \operatorname{HbA1c}(p=0.150)$, and diastolic $\mathrm{BP}(p=0.857)$ were not significant, as predicted by the model (Table 5).

\section{Discussion}

To the best of our knowledge, this is the first study in the Kingdom of Saudi Arabia that investigated the prevalence of cataract among the diabetic population; currently, there are limited population-based studies comparing DR patients with non-DR patients with regard to cataract development.

The prevalence of cataracts in our sample was $35.5 \%$, which is within the reported prevalence in the literature (18-50\%) [26]. Although many studies worldwide have shown that diabetes is associated with an increased risk for developing cataracts, the associated factors that increase or decrease this risk remain unclear [11, 13, 16-19, 22, 27, 28]. In this study, we report on some of these factors. Exploring the relationship of DM and cataract subtypes further, we found that cortical cataract was the most frequently observed subtype, followed by PSC, while NS was minimal, which is consistent with most of the previous studies [13, 17, 19, $21,29,30]$. Two studies reported contrasting finding - that
Table 4 Binary logistic regression (model 1) with backward elimination approach showing the relation between cataract and study variables

\begin{tabular}{llllllll}
\hline Parameters & $\beta$ & S.E. & Wald & $p$ value & OR & $95 \%$ C.I. & \\
\hline Diabetic retinopathy & 0.902 & 0.174 & 26.89 & $<\mathbf{0 . 0 0 1 *}$ & 2.464 & 1.752 & 3.465 \\
Age & 1.481 & 0.387 & 14.674 & $<\mathbf{0 . 0 0 1} *$ & 4.398 & 2.061 & 9.382 \\
Hypertension & 0.536 & 0.175 & 9.344 & $\mathbf{0 . 0 0 2} *$ & 1.710 & 1.212 & 2.412 \\
Gender & 0.422 & 0.172 & 6.022 & $\mathbf{0 . 0 1 4}$ & 1.525 & 1.089 & 2.137 \\
\hline
\end{tabular}

*Statistically significant at $5 \%$ level of significance

S.E. standard error, $O R$ odds ratio, C.I. confidence interval 
Table 5 Binary logistic regression (model 2) with backward elimination approach showing the relation to cataract, adjusted for study variables

\begin{tabular}{llllllll}
\hline Parameters & $\beta$ & S.E. & Wald & $p$ value & Adjusted OR & 95\% C.I. \\
\hline Age & 1.128 & 0.404 & 7.811 & $\mathbf{0 . 0 0 5} *$ & 3.089 & 1.401 & 6.814 \\
Gender & 0.163 & 0.190 & 0.740 & 0.390 & 1.177 & 0.812 & 1.707 \\
BMI & -0.010 & 0.013 & 0.547 & 0.460 & 0.991 & 0.966 & 1.016 \\
Systolic BP & 0.010 & 0.005 & 4.253 & $\mathbf{0 . 0 3 9 *}$ & 1.010 & 1.002 & 1.215 \\
Diastolic BP & -0.002 & 0.009 & 0.032 & 0.857 & 0.998 & 0.981 & 1.016 \\
Duration of diabetes & 0.048 & 0.012 & 15.482 & $<\mathbf{0 . 0 0 1} *$ & 1.049 & 1.024 & 1.074 \\
HbA1c & -0.111 & 0.077 & 2.073 & 0.150 & 0.895 & 0.769 & 1.041 \\
DR & 0.511 & 0.196 & 6.773 & $\mathbf{0 . 0 0 9 *}$ & 1.668 & 1.135 & 2.451 \\
\hline
\end{tabular}

* Statistically significant at $5 \%$ level of significance

$B P$ blood pressure, $B M I$ body mass index, DR diabetic retinopathy, S.E. standard error, $O \mathrm{R}$ odds ratio, C.I. confidence interval. is, NS was identified as the predominant subtype [26, 31]. Srinivasan et al. attributed the higher incidence of nuclear cataract in their study to a warmer climate and more exposure to the sun, relative to other studies; however, in our region, the climate is even hotter and sun exposure is much greater.

DR and cataract were significantly associated in our study; both unadjusted (odds ratio $=2.464 ; 95 \%$ $\mathrm{CI}=1.752-3.465, \quad p<0.001$ ) and adjusted (odds ratio $=1.668 ; 95 \% \mathrm{CI}=1.135-2.451, p=0.009)$ models were significant $(p<0.001)$, respectively. This is in accordance with the two studies conducted in the United Kingdom [32, 33]. A study in Brazil with a similar sample size to ours reported that cataract occurs four times more in diabetics with DR, which is 2.5 times what we found (1.67 times). This result may be due to the fact that they did not control for the duration of diabetes, which is a major confounding factor. Most of the risks of cataract in DR patients are due to the longer duration of DM, as DR is usually a late complication [34]. In the Wisconsin study, DR had the strongest association with cataract, but the study investigated type $1 \mathrm{DM}$ [18]; this study also reported that the severity of DR is one of the predictors of cataract surgery. In our study, there was no increase in the association of cataracts with any DR stage.

The incidence of cataract in diabetics with macular edema was found to be higher than that in the general diabetic population in the UK [32]. We did not find a significant relationship between cataract and CME. DR is mainly a vascular complication, while cataract is thought to be a biochemical complication of high blood glucose levels $[13,15]$. Why DR is a risk factor for cataract development needs to be studied further, as it may unveil some cataract pathology.

Our results showed a statistically significant association of cataract in patients with type $2 \mathrm{DM}$ with age and duration of DM, and it seems that there is almost consensus on these two factors in the literature [15, 18, 19, 21, 26, 28, 31-35]. Some studies reported higher risk for diabetic cataract in the younger age groups, which we did not find [11, 32, 36, 37].
Many previous studies have reported that diabetic women are at a higher risk of cataracts than diabetic men [21, 28, 31-33, 35, 36]; nevertheless, the underlying reason for this observation is unclear. However, theories have been suggested to explain that, like the role of estrogen in protecting the lens from oxidative stress, its decrease after menopause would increase the risk for cataract, as well as albumin to total protein and serum triglyceride levels in women [31, 35]. In our study, logistic regression model 1 revealed a significant association between sex and cataract $(p=0.012)$. The post hoc test revealed that cataract was significantly higher in men than in women $(p=0.027)$, while in logistic regression model 2 , no significant association was predicted. A possible reason for this result may be the higher number of males than females in the study sample, and the lower exposure of females to the sun in Saudi Arabia; however, further studies are required to confirm this speculation. Other studies have also found no significant difference in cataract development between sexes [38].

We found a significant association between hypertension and cataracts, specifically systolic BP. This finding is consistent with previous studies [18, 27, 34]. Similar to previous studies, we did not find a significant association between cataract and either BMI or obesity [31, 34]. However, other studies have related BMI to the incidence of cataract [27, 39].

In the present study, we found no association between $\mathrm{HbA} 1 \mathrm{c}$ and cataract; a similar finding was reported by Esteves et al. in Brazil [34]. They attributed this result to their study design or to the good metabolic control in their sample. However, many other researchers have reported a significant association between cataract and $\mathrm{HbA1c}[11,32,33$, 37]. One study reported a significant association between $\mathrm{HbA1c}$ and posterior sub-capsular cataracts, but not nuclear cataracts [21].

The incidence rates of cataract in our study were not affected by the use of insulin, whereas some previous studies found increased risk in patients using insulin $[18,32,33]$. 
This increased risk may be due to the higher percentage of diabetic complications in insulin users.

We examined a new factor, the age of onset of DM, and its relation to the development of cataract. Patients with diabetes with cataract had a significantly higher age of onset of diabetes $(p<0.001)$. To the best of our knowledge, this finding has not been previously reported. The possible reason for this association is that as DM develops late in life, patients are already at a higher risk of senile cataract. However, further exploration is needed to ascertain whether it is an independent variable.

Our study has several strengths. The source of our sample was a well-organized and updated primary care database and the sample was randomly selected from that source with very high response rate. The information on lens and fundus status was collected through the most accurate and reliable way (slit-lamp and indirect ophthalmoscope). We included several potential confounders in the analysis, like BP, BMI, insulin use, Hbalcand age of onset of diabetes.

The weakness in our study could be due to depending on history by patient in regard of insulin use and duration and age of onset of diabetes. In addition, BP was taken once in the clinic increasing the possibility of falls positive readings.

\section{Conclusion}

DR is an independent risk factor for cataract development in patients with type $2 \mathrm{DM}$. Other risk factors included age, duration of DM, and hypertension. Sex, BMI, HbA1c, and insulin use still need to be explored further. Age at onset of DM is a new factor that has been found to be significantly associated with the development of cataracts. Future studies should further investigate the association of age of onset in DM and cataract development.

Acknowledgements The author would like to acknowledge Dr. Waqqas Sami for his valuable input in the statistical analysis. Any data and materials related to this this study are available upon request from the Principal Investigator (Khalid Alabdulwahhab, email: k.alabdulwahhab@mu.edu.sa).

Funding The author also extend his appreciation to the Deanship of Scientific Research at Majmaah University for funding this work.

\section{Declarations}

Conflicts of interest The author reports no conflicts of interest in this work.

Open Access This article is licensed under a Creative Commons Attribution 4.0 International License, which permits use, sharing, adaptation, distribution and reproduction in any medium or format, as long as you give appropriate credit to the original author(s) and the source, provide a link to the Creative Commons licence, and indicate if changes were made. The images or other third party material in this article are included in the article's Creative Commons licence, unless indicated otherwise in a credit line to the material. If material is not included in the article's Creative Commons licence and your intended use is not permitted by statutory regulation or exceeds the permitted use, you will need to obtain permission directly from the copyright holder. To view a copy of this licence, visit http://creativecommons.org/licenses/by/4.0/.

\section{References}

1. Whiting DR, Guariguata L, Weil C, Shaw J. IDF diabetes atlas: global estimates of the prevalence of diabetes for 2011 and 2030. Diabetes Res Clin Pract. 2011;94(3):311-21. https://doi. org/10.1016/j.diabres.2011.10.029 ((epub 2011 Nov 12)).

2. Falck A, Laatikainen L. Diabetic cataract in children. Acta Ophthalmol Scand. 1998;76:238-40.

3. Bron AJ, Cheng H. Cataract and retinopathy: screening for treatable retinopathy. Clin Endocrinol Metab. 1986;15:971-99.

4. International Diabetes Federation. https://www.idf.org/about diabetes/what-is-diabetes/facts-figures.html. Accessed 15 Jun 2021.

5. Shaw JE, Sicree RA, Zimmet PZ. Global estimates of the prevalence of diabetes for 2010 and 2030. Diabetes Res Clin Pract. 2010;87(1):4.

6. Alqurashi K, Aljabri K, Bokhari S. Prevalence of diabetes mellitus in a Saudi community. Ann Saudi Med. 2011;31(1):19.

7. World Health Organization. https://www.who.int/blindness/ causes/. Accessed 15 Jun 2021.

8. Pascolini D, Mariotti SP. Global estimates of visual impairment: 2010. Br J Ophthalmol. 2012;96:614-8.

9. Khairallah M, Kahloun R, Bourne R, Limburg H, Flaxman SR, Jonas JB, et al. Number of people blind or visually impaired by cataract worldwide and in world regions, 1990 to 2010. Invest Ophthalmol Vis Sci. 2015;56:6762-9.

10. Khanna RC, Murthy GVS, Giridhar P, et al. Cataract, visual impairment and long-term mortality in a rural cohort in India: the Andhra Pradesh Eye Disease Study. PLoS ONE. 2013;8:e78002.

11. Klein BE, Klein R, Moss MS. Prevalence of cataracts in a population-based study of persons with diabetes mellitus. Ophthalmology. 1985;92:1191-6.

12. Klein R, Klein BE, Moss MS. Visual impairment in diabetics. Ophthalmology. 1984;91:1-8.

13. Pollreisz A, Schmidt-Erfurth U. Diabetic cataract-pathogenesis, epidemiology and treatment. J Ophthalmol. 2010;2010:608751.

14. Bhadania M. A review: cataract, a common ocular complication in diabetes. Int J Pharmacol Res. 2016;1(6):189-94.

15. Li X, Liu W, Huang X, Xiong J, Wei X. Interaction of AR and iNOS in lens epithelial cell: a new pathogenesis and potential therapeutic targets of diabetic cataract. Arch Biochem Biophys. 2017;615:44-52.

16. Javadi MA, Zarei-Ghanavati S. Cataracts in diabetic patients: a review article. J Ophthalmic Vis Res. 2008;3:52-65.

17. Li L, Wan XH, Zhao GH. Meta-analysis of the risk of cataract in type 2 diabetes. BMC Ophthalmol. 2014;14:94. https://doi.org/ 10.1186/1471-2415-14-94.

18. Klein BE, Klein R, Moss SE. Incidence of cataract surgery in the Wisconsin epidemiologic study of diabetic retinopathy. Am J Ophthalmol. 1995;119:295-300.

19 Klein BE, Klein R, Wang Q, Moss SE. Older-onset diabetes and lens opacities: the Beaver Dam Eye Study. Ophthalm Epidermol. 1995;2:49-55.

20. Tabin G, Chen M, Espandar L. Cataract surgery for the developing world. Curr Opin Ophthalmol. 2008;19(1):55-9. 
21. Olafsdottir E, Andersson DK, Stefánsson E. The prevalence of cataract in a population with and without type 2 diabetes mellitus. Acta Ophthalmol. 2012;90(4):334-40. https://doi.org/10.1111/j. 1755-3768.2011.02326.x ((epub 2011 Dec 16)).

22. Pizzol D, Veronese N, Quaglio G, Di Gennaro F, Deganello D, Stubbs B, Koyanagi A. The association between diabetes and cataract among 42,469 community-dwelling adults in six low- and middle-income countries. Diabetes Res Clin Pract. 2019;147:10210. https://doi.org/10.1016/j.diabres.2018.12.001 ((epub 2018 Dec 6)).

23. Chalmers JO, MacMahon S, Mancia G, et al. 1999 World Health Organization-International Society of Hypertension Guidelines for the management of hypertension. Guidelines sub-committee of the World Health Organization. Clin Exp Hypertens (New York, NY, 1993). 1998;21(5-6):1009-60.

24 Chylack LT Jr, Wolfe JK, Singer DM, Leske MC, Bullimore MA, Bailey IL, et al. The lens opacities classification system III. The Longitudinal Study of Cataract Study Group. Arch Ophthalmol. 1993;111:831-6.

25. Wilkinson CP, Ferris FL, Klein RE, et al. Proposed international clinical diabetic retinopathy and diabetic macular edema disease severity scales. Ophthalmology. 2003;110:1677-82.

26. Memon AF, Mahar PS, Memon MS, Mumtaz SN, Shaikh SA, Fahim MF. Age-related cataract and its types in patients with and without type 2 diabetes mellitus: a hospital-based comparative study. J Pak Med Assoc. 2016;66(10):1272-6.

27. Tan JSL, Wang JJ, Mitchell P. Influence of diabetes and cardiovascular disease on the long-term incidence of cataract: the Blue Mountains Eye Study. Ophthalmic Epidemiol. 2008;15(5):31727. https://doi.org/10.1080/09286580802105806.

28. Pék A, Szabó D, Sándor GL, Tóth G, Papp A, Nagy ZZ, Limburg $\mathrm{H}$, Németh J. Relationship between diabetes mellitus and cataract in Hungary. Int J Ophthalmol. 2020;13(5):788-93. https://doi.org/ 10.18240/ijo.2020.05.14.

29. Machan CM, Hrynchak PK, Irving EL. Age-related cataract is associated with type 2 diabetes and statin use. Optom Vis Sci. 2012;89(8):1165-71. https://doi.org/10.1097/OPX.0b013e3182 $644 \mathrm{~cd} 1$.

30 Schäfer C, Lautenschläger C, Struck HG. Kataraktformen bei Diabetikern und Nichtdiabetikern: eine densitometrische Studie mit der Topcon-Scheimpflug-Kamera [Cataract types in diabetics and non-diabetics: a densitometric study with the Topcon-Scheimpflug camera]. Klin Monbl Augenheilkd. 2006;223(7):589-92. https:// doi.org/10.1055/s-2006-926515 ((German)).

31. Srinivasan S, Raman R, Swaminathan G, Ganesan S, Kulothungan $\mathrm{V}$. Incidence, progression, and risk factors for cataract in type 2 diabetes. Invest Ophthalmol Vis Sci. 2017;58(13):5921-9. https:// doi.org/10.1167/iovs.17-22264.

32. Becker C, Schneider C, Aballéa S, Bailey C, Bourne R, Jick S, Meier C. Cataract in patients with diabetes mellitus-incidence rates in the UK and risk factors. Eye (Lond). 2018;32(6):1028-35. https://doi.org/10.1038/s41433-017-0003-1 ((epub 2018 Feb 1)).

33. Janghorbani MB, Jones RB, Allison SP. Incidence of and risk factors for cataract among diabetes clinic attenders. Ophthalmic Epidemiol. 2000;7(1):13-25.

34. Esteves JF, Dal Pizzol MM, Sccoco CA, Roggia MF, Milano SB, Guarienti JA, Rodrigues TC, Canani LH. Cataract and type 1 diabetes mellitus. Diabetes Res Clin Pract. 2008;82(3):324-8. https:// doi.org/10.1016/j.diabres.2008.08.023 ((epub 2008 Oct 15)).

35. Magnus Hugosson \& Curt Ekström. Prevalence and risk factors for age-related cataract in Sweden. Upsala J Med Sci. 2020;125(4):311-5. https://doi.org/10.1080/03009734.2020. 1802375.

36. Harding JJ, Egerton M, van Heyningen R, Harding RS. Diabetes, glaucoma, sex, and cataract: analysis of combined data from two case control studies. Br J Ophthalmol. 1993;77(1):2-6. https://doi. org/10.1136/bjo.77.1.2.

37. Ederer F, Hiller R, Taylor HR. Senile lens changes and diabetes in two population studies. Am J Ophthalmol. 1981;91(3):381-95. https://doi.org/10.1016/0002-9394(81)90293-2.

38. Foster PJ, Wong TY, Machin D, Johnson GJ, Seah SK. Risk factors for nuclear, cortical and posterior subcapsular cataracts in the Chinese population of Singapore: the Tanjong Pagar Survey. Br J Ophthalmol. 2003;87(9):1112-20. https://doi.org/10.1136/bjo. 87.9.1112.

39. Srinivasan M, Rahmathullah R, Blair CR, Murphy AC, Beck RW, Wilkins JH, Whitcher JP, Smolin G. Cataract progression in India. Br J Ophthalmol. 1997;81(10):896-900. https://doi.org/10.1136/ bjo.81.10.896. 